\title{
End of Ban on Women Driving in Saudi Arabia- Implications for Automobile Brands
}

\author{
Farah Ahmad \\ Dar Al Uloom University, Saudi Arabia \\ Yasser Mahfooz \\ King Saud University, Saudi Arabia
}

\begin{abstract}
INTRODUCTION
September 27, 2017 was a landmark date in the history of the Kingdom of Saudi Arabia as the long existing ban on women driving was lifted through a royal decree. Women were allowed to have a license and drive in the country from June 24, 2018 onwards. This created a new market segment for the automobile companies and almost every brand was visible with advertisements targeted at this newly emerged customer group. The female population of Saudi Arabia is expected to reach 15 million in 2020, and 20 percent of this population is projected to drive based on the age and income qualification (PWC, 2018). It is a tough challenge for car manufacturers as many companies are doing business here and everyone would like to get the maximum business from this segment. The companies have to make sure that their marketing strategies create the best results and position their brands positively.
\end{abstract}

A number of scholars such as Mackay, Romaniuk, and Sharp (1998) as well as Simon and Sullivan (1993) opined that brand equity is a viable option if a firm wants to assess the longrun effectiveness of its marketing programs on the firm's customers and revenue. It has indeed become evident that firms which engage in branding efforts benefit more in comparison to firms without a branding strategy (Capon, 2013). One of the key outcomes of branding which is evident in literature is brand equity (Narteh, 2018). Brand equity is defined as the "differential effect of brand knowledge on consumer response to the marketing of the brand" (Keller, 1993). It has become an important concept in marketing, as manufacturers are strategizing to expand customer base at local and global level. Now an additional variable during price setting exercise, it helps to command a premium price that a customer willingly pays. It has also become an extensively discussed concept in marketing research (Yasin, Noor, \& Mohamad, 2007; Chang, 2014).

Brand equity depends on the perception of consumers towards a brand, which depend on various factors. Researchers have provided an understanding of variables that lead to brand equity (Aaker, 1991, 1996; Keller, 1993; Cobb-Walgren, Ruble, \& Donthu, 1995; Yoo, Donthu, \& Lee, 2000), and the most commonly listed variables leading to brand equity are brand awareness, perceived quality, brand association, and brand loyalty. The most recent study identified from the Middle East region was by Mahfooz (2015) which focused primarily on the male customers as females were not allowed to drive during the period of data collection. Since women are now allowed to drive in Saudi Arabia, hence this study fills the gap as no research was found for this market..

According to a PWC report (2018), sales of cars is expected to grow by 9 percent per annum until 2025 boosted by the new women customer segment. The areas of immediate opportunity which were identified in this report are car sales, car leasing, driving schools, and insurance. 
The annual growth rate for car leasing is expected to pick up substantially with an annual growth rate of 4 percent until 2025. Moreover, rising disposable income coupled with ease of automobile financing are expected to further boost demand for passenger cars in Saudi Arabia through 2025. Some of the major automobile brands here include BMW, Mercedes, Porsche, Toyota, Honda, Nissan, Hyundai, Ford among many others. According to Arab News, KSA is the $20^{\text {th }}$ largest market for cars in the world; largest importer of cars and spare parts as well as the largest in terms of registration in the Middle East region comprising countries, such as the United Arab Emirates, Qatar, Kuwait, Bahrain etc. (Murad, 2014). The demand for cars has been driven by a growth in youth population, complemented by an increased buying capacity. After the royal decree allowing women to drive, the demand for cars will increase further. These factors have led to an increase of interest for marketers to reap the benefits in the years to come. The primary challenge is to differentiate the product from competitors, and various branding exercises are already in place. The important contribution of this research is to identify key antecedents of brand equity, and the role of brand equity in increasing trust and purchase intention.

\section{THEORETICAL BACKGROUND}

Brand equity helps a company in creating value for the target market, which in turn leads to an increase in sales (Park and Srinivasan, 1994; Delgado-Ballester \& Munuera-Aleman, 2005; Hooley et al., 2005). The earliest research on brand equity was by Cobb-Walgren et al. (1980). From the early years of its development, various researchers have proposed definitions and models to measure the same. Farquhar (1989) defined it as a value delivered to a product by a brand. This definition was further expanded to include brand assets and liabilities that consumers associate with a brand, and signifying a value provided by a product to its customers (Aaker, 1991, 1996). These researches were supported by Keller (1993), who proposed a definition based on the response of consumers toward marketing of a brand, which was based on the brand knowledge. Yoo et al. (2000) defined it on the basis of consumer choice, which was based on the difference between branded and unbranded product. Consumer decision making is based on the value provided by a product/brand. Yasin et al. (2007) related the value of a brand in terms of brand equity to the product's position in the mind of consumers. If a consumer thinks positive about the brand, then it has high brand equity, and vice-versa. The term brand equity has various connotations; and no consensus is found on an acceptable meaning and its dimensions (Yoo \& Donthu, 2001; Vazquez et al., 2002; Washburn \& Plank, 2002; Keller, 2003; Atilgan et al., 2005; Pappu et al., 2005). The concept of brand equity is mostly defined as the knowledge of customers as well as the brand value created through consistent efforts in marketing (Aaker, 1991; Keller, 1993; Pappu et al., 2005; Yasin et al., 2007; Amjad \& Muhammad, 2013).

Research also focused on the antecedents and consequences of brand equity (Chen \& Chang, 2008; Amjad \& Muhammad, 2013). The perceptions included brand awareness, brand associations, and perceived quality; and behavior comprising of brand loyalty. Other consequences like brand preference, purchase intention, repurchase intention were also identified. Researchers have proposed various models and indirect measures to measure brand equity and building of strong brands, and these models consider it to be multidimensional construct (Aaker, 1991; Keller, 1993; Yoo et al., 2000; Pappu et al., 2005; Ha, Janda, \& Muthaly, 2010; Amjad \& Muhammad, 2013). The brand equity model provided by Aaker (1991) has dominated the literature on consumer perceptions (Ha et al., 2010; Chang, 2014). This comprises of brand awareness, perceived quality, brand associations and brand loyalty. 


\section{After Sales Service and Brand Equity}

\section{HYPOTHESES DEVELOPMENT AND CONCEPTUAL MODEL}

Automobile sector operates on a hybrid model which makes it dependent on authorized dealers providing assistance through sales and after sales service. Previous research has suggested that authorized dealers providing sales assistance and after sales service in automobile sector play a critical role in branding (Ahmad \& Butt, 2012). After sales service is also found to enhance the perception of a brand and can be used as a tool to counter competition (Asugman et al., 1997; Rigopoulou et al., 2008). Research has also shown that the knowledge of a brand depends on the availability of after sales service for the customers (Ehinlanwo \& Zairi, 1996), and the after sales service is also found to influence brand equity (Eagle et al., 2003; Ahmad \& Butt, 2012). Thus the following hypothesis is formulated:

H1: After sales service has a positive effect on brand equity.

\section{Brand Association and Brand Equity}

Brand association relates to the features of a product (Maderer et al., 2016) and is considered to be a dimension of brand equity and can be anything which links to the memory of a brand (Aaker, 1991). Association to a brand is a differentiator (del Rio, Vazquez, \& Iglesias, 2001), as it helps in the recall of brand information, provides a purpose of purchase, and evokes positive feeling (Aaker, 1991; Narteh, 2018). Aaker (1991) proposed brand association as a dimension of brand equity, which is tested by researchers (Ye \& van Raaij, 2004; Pappu \& Quester, 2006; Tong \& Hawley, 2009; Buil et al., 2013; Kumar et al., 2013). A strong positive brand association was found to imply that brand will have a higher equity (Mahfooz, 2015). Thus, the following hypothesis is formulated:

H2: Brand association has a positive effect on brand equity.

\section{Brand Awareness and Brand Equity}

Brand awareness is the first step when a customer commits to a brand, and is very often attributed to the loyalty towards a brand (Hsu, Oh, \& Assaf, 2012). The awareness of a brand makes it powerful (Narteh, 2018), and hence can be considered as an essential for creating brand equity (Keller, 2003; Buil, Martinez, \& de Chernatony, 2013). It signifies how well a prospective customer can recognize a brand and its product category (Aaker, 1991, 1996). It is found to contribute significantly in decision making (Keller, 2003) and results in customerbased brand equity (Aaker, 1996; Narteh, 2018). Customers are found to purchase those brands, which they can identify (Bojei \& Hoo, 2012), and awareness signifies reputation and familiarity (Yasin et al., 2007). Researchers have found brand awareness as a key dimension of brand equity (Pappu \& Quester, 2006; Yasin et al., 2007; Tong \& Hawley, 2009; Kumar, Dash, \& Purwar, 2013; Narteh, 2018). Thus, the following hypothesis is formulated:

H3: Brand awareness has a positive effect on brand equity.

\section{Brand Loyalty and Brand Equity}

Brand loyalty is a core dimension of brand equity (Kumar et al., 2013) and is defined by Aaker (1991) as the likeliness of a customer to switch to another brand if a change in features or price happens. Keller (2003) referred to it as the relationship between customer and a brand, and the relatedness of customer with the brand. Aaker (1991) defined brand loyalty as a dimension of brand equity, which was confirmed in many future research (Yoo et al., 2000; Atilgan et al., 2005; Delgado-Ballester \& Munuera-Aleman, 2005; Pappu \& Quester, 2006; Gil, Andres, \& Salinas, 2007; Yasin et al., 2007; Tong \& Hawley, 2009; Buil et al., 2013). Thus, the following hypothesis is formulated:

H4: Brand loyalty has a positive effect on brand equity. 


\section{Perceived Quality and Brand Equity}

Perceived quality is the perception of quality or superiority of an offering (Zeithaml, 1988; Buil et al., 2013). It develops the perception of a brand as different from others (Aaker, 1996, Ha et al., 2010), and influences its purchase decision (Ha et al., 2010). Perceived quality is considered to be a dimension of customer-based brand equity (Farquhar, 1989; Aaker, 1991), and is supported by researches (Yoo et al., 2000; Netemeyer et al., 2004; Pappu \& Quester, 2006; Tong \& Hawley, 2009; Buil et al., 2013; Kumar et al., 2013). Thus, the following hypothesis is formulated:

H5: Perceived quality has a positive effect on brand equity.

\section{Brand Equity, Brand Trust and Purchase Intention}

One of the early definitions of trust was given by Deutsch (1973), and meant trust to be a confidence of finding what is desired, rather than what was not expected or feared. The brand trust was defined as the confidence of a consumer to receive consistency, responsibility, and honesty in the brand itself (Andaleeb, 1992; Delgado-Ballester \& Munuera-Alemán, 2005). Researchers have also focused on the relationship between brand trust and brand equity (Kumar et al., 2013), and very often it has been conceptualized as a dimension of brand equity (Chaudhuri \& Holbrook, 2001; Burmann et al., 2009; Kumar et al., 2013). Holehonnur et al. (2009) as well as Amjad and Muhammad (2013) found that brand equity has a positive influence on purchase intention. Purchase intention is defined as the plan of a customer for the purchase of a specific brand (Chang \& Liu, 2009). Empirical studies have shown that brand equity affects purchase intention (Cobb-Walgren et al., 1995; Ashill and Sinha, 2004; Chang \& Liu, 2009; Jalilband \& Samiei, 2012). Researchers have also explored the association between brand trust and purchase intention. Chaudhuri and Holbrook (2001), Esch et al. (2006), Kang and Hur (2012), and Ali et al. (2018) have found a positive relationship between brand trust and purchase intention. Thus, the following hypotheses are formulated:

H6: Brand equity has a positive effect on brand trust

H7: Brand equity has a positive effect on purchase intention.

H8: Brand trust has a positive effect on purchase intention

\section{Conceptual Model}

The conceptual model in figure 1 is based on the developed hypotheses. The dimensions provided by Aaker (1991) and after sales service are considered as the antecedent to brand equity. Brand trust along with purchase intention is considered as the consequence of brand equity. Brand trust can also be considered as a mediator between brand equity and purchase intention. For a successful application of brand equity concept, all antecedent-consequence relationships need to be assessed. 


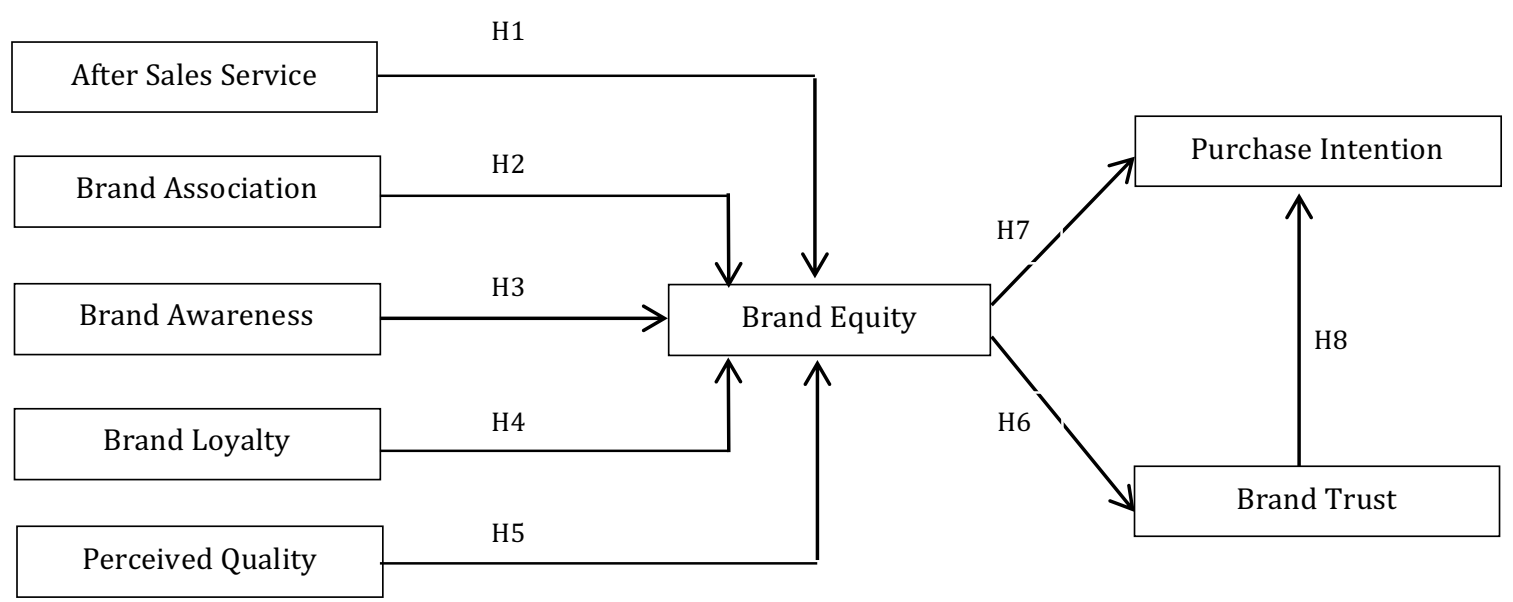

Figure 1: Conceptual Model

\section{Instrument}

\section{METHOD}

The measurement scale has eight constructs. In the initial questionnaire, 5 items for brand awareness (BAW), 4 for perceived quality (PQ), 4 for brand association (BAS), and 4 for brand loyalty (BL) were adapted from Aaker (1991), Yoo et al. (2000), and Yasin et al. (2007); 2 items for after sales service (AS) were adapted from Ahmad and Butt (2012); 5 items for brand equity (BE) were adapted from Yoo and Donthu (2001); 3 items for brand trust (BT) were adapted from Han et al. (2015); and 2 items for purchase intention (PI) were adapted from Cobb-Walgren et al. (1995) and de Chernatony et al. (2004). All items were measured on a 5 point scale with 1 representing strongly disagree, and 5 representing strongly agree. The first section of the questionnaire was used to collect data on demography of the respondents, and the second section had measuring variables proposed in the conceptual model. Respondents had to answer the survey questions keeping in mind their favorite brand of cars.

\section{Data Collection}

Data was collected from females in three cities- Riyadh, Jeddah, and Dammam. These are the largest and the most populated cities in center, west and east of the Kingdom of Saudi Arabia. Data was collected online using purposive sampling technique. The respondents were eligible for a license or recently got it issued from within Saudi Arabia. Out of the 231 responses received, 226 were found to be valid for the purpose of analysis. The missing values in the data were replaced using the mean score substitution procedure as suggested by Tabachnick and Fidell (2001).

The maximum respondents are from 26-35 years age group (45.3 percent), and have completed under-graduate level education (58.6 percent). Majority of the respondents were working in private sector, whereas the least was in government jobs. Also, a high percentage of respondents were found to be unmarried (65.4\%).

\section{DATA ANALYSIS}

The relationships in conceptual model of this study are assessed by structural equation modeling (SEM) through SmartPLS 3.2. SmartPLS was chosen for the analysis because it follows the variance-based SEM approach, which is less sensitive to sample size as compared to other applications using covariance-based approaches like AMOS. 


\section{Reliability and Validity}

Before testing the hypothesized relationships, the reliability and validity of the scales was assessed. Table 1 shows the result for construct reliability through internal consistency (Cronbach's Alpha, $\alpha$ ) and Composite Reliability. The internal consistency was assessed through Cronbach's $\alpha$ for the factors After Sales Service, Brand Association, Brand Awareness, Brand Equity, Brand Loyalty, Brand Trust, Purchase Intention, and Perceived Quality; and was found to be $0.818,0.881,0.937,0.933,0.863,0.905,0.892$, and 0.931 respectively. The values are acceptable as they were found to be greater than the recommended value of 0.70 (Nunnally, 1988). After data screening, a total of 7 items (Brand Association=1, Brand Awareness $=2$, Brand Loyalty $=1$, Perceived Quality $=1$, Brand Equity $=2$ ) were removed due to low reliability and outliers.

\begin{tabular}{|c|c|c|c|}
\hline Constructs & Cronbach's Alpha $(\alpha)$ & Composite Reliability & AVE* $^{*}$ \\
\hline AS & 0.818 & 0.916 & 0.845 \\
\hline BAS & 0.881 & 0.927 & 0.808 \\
\hline BAW & 0.937 & 0.960 & 0.888 \\
\hline BE & 0.933 & 0.957 & 0.882 \\
\hline BL & 0.863 & 0.916 & 0.784 \\
\hline BT & 0.905 & 0.940 & 0.839 \\
\hline PI & 0.892 & 0.948 & 0.902 \\
\hline PQ & 0.931 & 0.956 & 0.879 \\
\hline *AVE $=$ Average Variance Extracted & & \\
\hline
\end{tabular}

\section{Table 1: Construct Reliability}

The validity of instrument was also assessed through convergent validity. The values of Average Variance Extracted (AVE) mentioned in table 1 are used to assess the convergent validity as suggested by Hair, Black, Babin, Anderson, and Tatham (2006). The AVE of all constructs as shown in the table was in the range 0.784-0.902, which exceeded the recommended value of 0.5 (Hair et al., 2006). This establishes the measurement model and confirms both the construct validity and the convergent validity.

In addition to the construct reliability and the convergent validity, the scale must also achieve discriminant validity. To establish discriminant validity, the AVE for each construct must be greater than the shared variance among the constructs. The square root of each of the eight constructs is greater than the correlation of other constructs. The values are provided in table 2. This established the discriminant validity.

\begin{tabular}{|c|c|c|c|c|c|c|c|c|}
\hline Constructs & & & & & & & & \\
\hline & AS & BAS & BAW & BE & BL & BT & PI & PQ \\
\hline AS & 0.919 & & & & & & & \\
\hline BAS & 0.835 & 0.899 & & & & & & \\
\hline BAW & 0.798 & 0.877 & 0.942 & & & & & \\
\hline BE & 0.860 & 0.881 & 0.873 & 0.939 & & & & \\
\hline BL & 0.850 & 0.825 & 0.797 & 0.848 & 0.886 & & & \\
\hline BT & 0.725 & 0.753 & 0.733 & 0.778 & 0.679 & 0.916 & & \\
\hline PI & 0.509 & 0.545 & 0.540 & 0.539 & 0.457 & 0.517 & 0.950 & \\
\hline PQ & 0.831 & 0.862 & 0.857 & 0.885 & 0.802 & 0.819 & 0.576 & 0.938 \\
\hline
\end{tabular}

Table 2: Discriminant Validity 


\section{Hypotheses Testing}

For the calculation of path estimates and the corresponding t-values and p-values, SmartPLS 3.2 was used with a bootstrapping technique. The results are presented in table 3 . The relationships are significant ( $p<0.05)$, which supports all hypotheses H1-H8. The standardized coefficients $(\beta)$ are in the hypothesized direction, and are used to assess the contribution of independent variables on brand equity which supports $\mathrm{H} 1-\mathrm{H} 5$. The test also reveals a significant antecedent-consequence relationship of brand equity with brand trust and purchase intention, and also the relationship between brand trust and purchase intention. This supports H6-H8.

\begin{tabular}{|c|c|c|c|c|c|}
\hline Type of Relationship & Path & Estimates $(\beta)$ & t-values & $p$-values & Hypothesis \\
\hline \multicolumn{6}{|l|}{ Direct effects } \\
\hline & $\mathrm{AS}->\mathrm{BE}$ & 0.179 & 2.299 & 0.022 & $\mathrm{H} 1$ \\
\hline & BAS -> BE & 0.174 & 2.622 & 0.009 & $\mathrm{H} 2$ \\
\hline & $\mathrm{BAW}->\mathrm{BE}$ & 0.216 & 4.340 & 0.000 & $\mathrm{H} 3$ \\
\hline & $\mathrm{BL}->\mathrm{BE}$ & 0.164 & 2.757 & 0.006 & $\mathrm{H} 4$ \\
\hline & $P Q->B E$ & 0.270 & 4.240 & 0.000 & H5 \\
\hline & $\mathrm{BE}->\mathrm{BT}$ & 0.778 & 24.315 & 0.000 & H6 \\
\hline & $\mathrm{BE}->\mathrm{PI}$ & 0.345 & 3.136 & 0.002 & $\mathrm{H} 7$ \\
\hline & BT -> PI & 0.249 & 2.387 & 0.017 & H8 \\
\hline \multicolumn{6}{|l|}{ Indirect Effects } \\
\hline & $\mathrm{BE}->\mathrm{BT}->\mathrm{PI}$ & 0.194 & 2.328 & 0.020 & \\
\hline
\end{tabular}

\section{Mediated Effects}

Table 3: Hypotheses Testing

The mediating effect of brand trust was examined through the indirect effect of brand equity on purchase intention through brand trust. The results indicate that the indirect effect of brand equity $(\beta=0.194, p=0.020)$ on purchase intention was significant. As the both the direct and indirect effects of brand equity on purchase intention were significant thus brand equity partially mediates the relationship of independent variable brand equity and purchase intention. All hypotheses were accepted and the results of SmartPLS path model are shown in figure 2

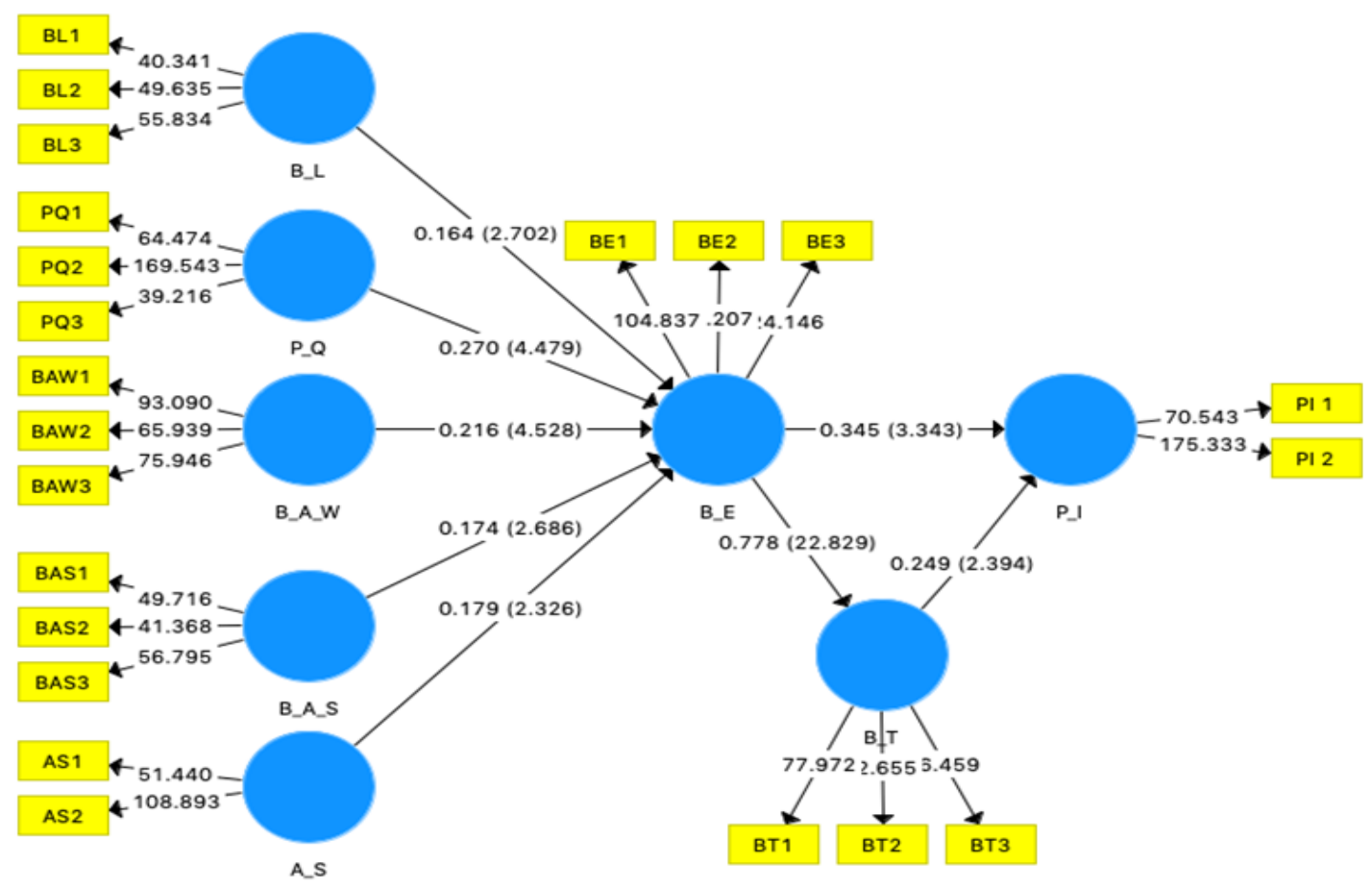

Figure 2: SmartPLS Path Model 


\section{CONCLUSION AND SUGGESTION}

The findings confirm that all four dimensions of brand equity proposed by Aaker (1991) along with after sales service has a significant positive relationship with brand equity. This confirms that an increase in any of the five variables will lead to an increase in the brand equity. Although results of data analysis confirmed that all five proposed antecedents contribute to brand equity; perceived quality was found to have a dominant effect on brand equity $(\beta=$ $0.270)$ followed by brand awareness $(\beta=0.216)$. This doesn't conform to previous researches by Atilgan et al. (2005), Delgado-Ballester \& Munuera-Aleman (2005), Yasin et al. (2007), Gil et al. (2007), Buil et al. (2013), and Mahfooz (2015). The research by Mahfooz (2015) is focused on Saudi Arabia, still the results vary because during its research, the female respondents were not real consumers as the law didn't permit them to drive. An inability to drive means the females won't purchase a car to drive and hence won't be interested in increasing their knowledge about the existing brands in the market. The brand awareness, brand association and brand loyalty are inter-related. After sales service also happens if one owns a car, otherwise this loses significance. Once allowed to drive, the intention to gather information about products which could fulfill the need increases. The initial perception will be developed on the basis of how the brands are positioned in the communication by various companies. The present research shows that the best strategy for positioning is to highlight the quality of their product. This will generate higher level of brand equity and further lead to brand trust and purchase intention. Since advertising can have a positive effect on brand equity (Eagle et al., 2003), the positioning can be communicated effectively through advertisements in appropriate media.

The conceptual model also tested brand trust and purchase intention as a consequence of overall brand equity. A significant positive relationship which doesn't support previous research which found brand trust to be an element of brand equity and not the consequence (Chaudhuri \& Holbrook, 2001; Burmann et al., 2009; Kumar et al., 2013). This implies that an increase in brand equity will lead to an increase in the trust and intention to buy a specific brand of cars. During the buying decision process, the positive perception of quality will be an advantage as the product will find a place in the evoked set and finally lead to a purchase intention for the same brand.

In the conceptual framework, all individual hypotheses were supported and established a significant positive relationship for the brand of cars available in the country. This framework provides a better understanding of various influencers for female customers of cars. This research provides an overview of the antecedents and consequences of brand equity, which can assist marketing personnel to have a clear understanding of the factors affecting brand equity, and lead them to make appropriate strategies to target the newly emerged market segment which has a strong potential to expand in near future.

\section{LIMITATION}

This study has its limitations, which primary relates to the sampling and online data collection. The sample is chosen from only three cities, which may limit the generalization for the entire country.

\section{References}

Aaker, D. A. (1991). Managing Brand Equity: Capitalizing on the value of a brand name, NY: The Free Press.

Aaker, D. A. (1996). Measuring brand equity across products and markets. California Management Review, 38(3), 102-120.

Ahmad, S., \& Butt, M. M. (2012). Can after sale service generate brand equity? Marketing Intelligence \& Planning, 30(3), 307-323. 
Ali, A., Xiaoling, G., Sherwani, M., \& Ali, A. (2018). Antecedents of consumers' Halal brand purchase intention: An integrated approach. Management Decision, 56(4), 715-735.

Amjad, S., \& Muhammad, M.B. (2013). A critical model of brand experience consequences. Asia Pacific Journal of Marketing and Logistics, 25(1), 102-117

Andaleeb, S. S. (1992). The trust concept: Research issues for channels of distribution. Research in Marketing, 11(1), 1-34.

Ashill, N. J., \& Sinha, A. (2004). An exploratory study into the impact of components of brand equity and country of origin effects on purchase intention. Journal of Asia-Pacific Business, 5(3), 27-43.

Asugman, G., Johnson, J. L., \& McCullough, J. (1997). The role of after-sales service in international marketing. Journal of International Marketing, 5(4), 11-28.

Atilgan, E., Aksoy, S., \& Akinci, S. (2005). Determinants of the brand equity: A verification approach in the beverage industry in Turkey. Marketing Intelligence \& Planning, 23(3), 237-248.

Bailey, R., \& Ball, S. (2006). An exploration of the meanings of hotel brand equity. The Service Industries Journal, 26(1), 15-38.

Bojei, J. \& Hoo, W. C. (2012). Brand equity and current use as the new horizon for repurchase intention of smartphone. International Journal of Business and Society, 13(1), 33-48.

Buil, I., de Chernatony, L., \& Martínez, E. (2008). A cross-national validation of the consumer based brand equity scale. Journal of Product \& Brand Management, 17(6), 384-392.

Buil, I., Martínez, E. \& de Chernatony, L. (2013). The influence of brand equity on consumer responses. Journal of Consumer Marketing, 30(1), 62-74.

Burmann, C., Jost-Benz, M., \& Riley, N. (2009). Towards an identity-based brand equity model. Journal of Business Research, 62(3), 390-397.

Business Monitor Report (2014). Saudi Arabia Auto's Report, October 1, 1-75.

Chang, H. H. \& Liu Y. M. (2009). The impact of brand equity on brand preference and purchase intentions in the service industries. The Service Industries Journal, 29(12), 1687-1706.

Chang, E.-C. (2014). Influences of the spokes-character on brand equity antecedents. Asia Pacific Journal of Marketing and Logistics, 26(3), 494-515.

Chaudhuri, A. (1999). Does brand loyalty mediate brand equity outcomes. Journal of Marketing Theory and Practice, 7(2), 136-146.

Chaudhuri, A., \& Holbrook, M. B. (2001). The chain of effects from brand trust and brand affect to brand performance: the role of brand loyalty. Journal of Marketing, 65(2), 81-93.

Chen, C.-F., Chang, Y.-Y. (2008). Airline brand equity, brand preference, and purchase intentions- The moderating effects of switching costs. Journal of Air Transport Management, 14(1), 40-42.

Cobb-Walgren, C.J., Ruble, C.A., \& Donthu, N. (1995). Brand equity, brand preference, and purchase intent. Journal of Advertising, 24(3), 25-40.

de Chernatony, L., Harris, F., \& Christodoulides, G. (2004). Developing a brand performance measure for financial services brands. The Service Industries Journal, 24(2), 15-33.

del Rio, A. B., Vazquez, R., \& Iglesias, V. (2001). The effects of brand associations on consumer response. Journal of Consumer Marketing, 18(5), 410-425.

Delgado-Ballester, E., \& Munuera-Alemán, J. L. (2005). Does brand trust matter to brand equity? Journal of Product \& Brand Management, 14(3), 187-196.

Deutsch, M. (1973). The Resolution of Conflict: Constructive and Destructive Processes. CT: Yale University Press, New Haven.

Devlin, J. F., Gwynne, A. L., \& Ennew, C. T. (2002). Antecedents of service expectations. The Services Industries Journal, 22(4), 117-131.

Eagly, A. H., \& Chaiken, S. (1993). The psychology of attitudes. Harcourt Brace Jovanovich College Publishers.

Eagle, L., Kitchen, P. J., Rose, L., \& Moyle, B. (2003). Brand equity and brand vulnerability: The impact of gray marketing/parallel importing on brand equity and values. European Journal of Marketing, 37(10), 1332-1349. 
Ehinlanwo, 0.0., \& Zairi, M. (1996). Best practice in the car after-sales service: An empirical study of Ford, Toyota, Nissan and Fiat in Germany- Part 1. Business Process Re-engineering and Management Journal, 2(2), 39-56.

Esch, F. R., Langner, T., Schmitt, B. H., \& Geus, P. (2006). Are brands forever? How brand knowledge and relationships affect current and future purchases. Journal of Product \& Brand Management, 15(2), 98-105.

Farquhar, P. H. (1989). Managing brand equity. Marketing Research, 1(3), 24-33.

Gil, R. B., Andres, E., F., \& Salinas, E. M. (2007). Family as a source of consumer-based brand equity. Journal of Product \& Brand Management, 16(3), 188-199.

Ha, H.-Y., Janda, S., \& Muthaly, S. (2010). Development of brand equity: Evaluation of four alternative models. The Service Industries Journal, 30(6), 911-928.

Hair, J. F., Black, W. C., Babin, B. J., Anderson, R. E., \& Tatham, R. L. (2006). Multivariate data analysis (Vol. 6). NJ: Pearson Prentice Hall, Upper Saddle River.

Hellier, P. K., Geursen, G. M., Carr, R. A., \& Rickard, J. A. (2003). Customer repurchase intention: A general structural equation model. European Journal of Marketing, 37(11/12), 1762-1800.

Holehonnur, A., Raymond, M. A., Hopkins, C. D., \& Fine, A. C. (2009). Examining the customer equity framework from a consumer perspective. Journal of Brand Management, 17(3), 165-180.

Hooley, G.I., Greenley, G.E., Cadogan, J.W., \& Fahy, J. (2005). The performance impact of marketing resources. Journal of Business Research, 58(1), 18-27.

Hsu, C. H., Oh, H., \& Assaf, A. G. (2012). A customer-based brand equity model for upscale hotels. Journal of Travel Research, 51(1), 81-93.

Irmscher, M. (1993). Modelling the brand equity concept. Marketing and Research Today, 21(2), 102-110.

Jalilvand, M. R., \& Samiei, N. (2012). The effect of electronic word of mouth on brand image and purchase intention: An empirical study in the automobile industry in Iran. Marketing Intelligence \& Planning, 30(4), 460476.

Kang, S., \& Hur, W. M. (2012). Investigating the antecedents of green brand equity: A sustainable development perspective. Corporate Social Responsibility and Environmental Management, 19(5), 306-316.

Keller, K. L. (1993). Conceptualizing, measuring, managing customer-based brand equity. Journal of Marketing, 57(1), 1-22.

Keller, K. L. (2003). Strategic Brand Management: Building, measuring, and managing brand equity, NJ: Prentice Hall, Upper Saddle River.

Kotler, P., Keller, K. L., Hassan, S. S., Baalbaki, I. B., \& Shamma, H. M. (2012). Marketing Management (Arab World Edition), England: Pearson Education.

Kumar, R. S., Dash, S., \& Purwar, P. C. (2013). The nature and antecedents of brand equity and its dimensions. Marketing Intelligence \& Planning, 31(2), 141-159.

Mackay, M. M., Romaniuk, J., \& Sharp, B. (1998). A classification of brand equity research endeavours. Journal of Brand Management, 5(6), 415-429.

Maderer, D., Holtbruegge, D., \& Woodland, R. (2016). The impact of brand associations on brand loyalty in the football industry: A comparison of fans from developed and emerging football markets. Sport, Business and Management: An International Journal, 6(5), 499-519.

Mahfooz, Y. 2015. Brand Equity-Consequence relationship: Evidence from Automobile industry. International Journal of Business and Management, 10(3), 81-90.

Murad, A. (2014), Kingdom's auto sales heading toward critical mass of 1m units. Arab News, December 16, 13.

Myers, C. A. (2003). Managing brand equity: A look at the impact of attributes. Journal of Product \& Brand Management, 12(1), 39-51.

Narteh, B. 2018. Brand equity and financial performance: The moderating role of brand likeability. Marketing Intelligence \& Planning, 36(3), 381-395.

Netemeyer, R.G., Krishnan, B., Pullig, C., Wang, G., Yagci, M., Dean, D., Ricks, J., \& Wirth, F. (2004). Developing and validating measures of facets of customer-based brand equity. Journal of Business Research, 57(2), $209-224$.

Nunnally, J. C. (1988). Psychometric Theory. NJ: McGraw-Hill, Englewood-Cliffs. 
Pappu, R., Quester, P. G., \& Cooksey, R. W. (2005). Consumer-based brand equity: Improving the measurementempirical evidence. Journal of Product \& Brand Management, 14(3), 143-154.

Pappu, R. \& Quester, P. (2006). Does customer satisfaction lead to improved brand equity? An empirical examination of two categories of retail brands. Journal of Product \& Brand Management, 15(1), 4-14.

Park, C.S., \& Srinivasan, V. (1994). A survey-based method for measuring and understanding brand equity and its extendibility. Journal of Marketing Research, 31(2), 271-288.

Prasad, K., \& Dev, C. S. (2000). Managing hotel brand equity: A customer-centric framework for assessing performance. Cornell Hotel and Restaurant Administration Quarterly, 41(3), 22-31.

PWC 2018. Women driving the transformation of the KSA automotive market.

https://www.pwc.com/m1/en/publications/documents/women-driving-the-transformation-of-the-ksaautomotive-market.pdf

Rigopoulou, I. D., Chaniotakis, I. E., Lymperopoulos, C., \& Siomkos, G. I. (2008). After-sales service quality as an antecedent of customer satisfaction: The case of electronic appliances. Managing Service Quality: An International Journal, 18(5), 512-527.

Tabachnick, B.G., \& Fidell, L.S. (2001). Using Multivariate Statistics, MA: Allyn \& Bacon, Boston.

Tong, X. \& Hawley, J. M. (2009). Measuring customer-based brand equity: Empirical evidence from the sportswear market in China. Journal of Product \& Brand Management, 18(4), 262-271.

Vazquez, R., del Rio, A. B., \& Iglesias, V. (2002). Consumer-based brand equity: Development and validation of a measurement instrument. Journal of Marketing Management, 18(1/2), 27-48.

Washburn, J. H. \& Plank, R. E. (2002). Measuring brand equity: An evaluation of a consumer based brand equity scale. Journal of Marketing Theory and Practice, 10(1), 46-61.

Yasin, N. M., Noor, M. N., \& Mohamad, O. (2007). Does image of country-of-origin matter to brand equity?. Journal of Product \& Brand Management, 16(1), 38-48.

Ye, G., \& van Raaij, W.F. (2004). Brand equity: Extending brand awareness and liking with signal detection theory. Journal of Marketing Communication, 10(2), 95-114.

Yoo, B., Donthu, N., \& Lee, S. (2000). An examination of selected marketing mix elements and brand equity. Journal of the Academy of Marketing Science, 28(2), 195-211.

Yoo, B., \& Donthu, N. (2001). Developing and validating a multidimensional consumer-based brand equity scale. Journal of Business Research, 52(1), 1-14.

Zeithaml, V. A. (1988). Consumer perceptions of price, quality, and value: a means-end model and synthesis of evidence. Journal of Marketing, 52(3), 2-22. 